\title{
PERFORMANCE-OPTIMAL PHASE-LOCKED SYSTEM FOR DEVICE OF SYNCHRONIZATION AND FORMATION OF THE EXACT TIME SIGNALS
}

\author{
Dmytro Kalian \\ National University of Life and Environmental Sciences of Ukraine, Kyiv, Ukraine
}

Background. The generating reference time signals problem to meet the all consumers' requirements for time and frequency information is targeted on researching the time scale IP-technologies transmission systems quality improvement and optimizing the synchronization devices self-tuning, as one of the most common systems' elements in a today's world.

Objective. The aim of the paper is the phase locked loop (PLL) system performance optimization of the device for the exact time signal synchronization and formation.

Methods. The linearized model construction of a closed automatic control system for a synchronization device, obtaining performance optimal control law in an analytical form and its implementation in the synchronization device PLL system using an adaptive digital phase discriminator.

Results. The performance optimal control law in synchronization PLL device using an adaptive digital phase discriminator was practically implemented.

Conclusions. The synchronization information transmission over existing IP networks based on the PTP protocol allows spreading the time scale with an accuracy of hundreds nanoseconds in real networks. Improving the exact time signals formation quality causes the optimizing performance need for the PLL synchronization devices. The adaptive digital phase discriminator use is protected by the Ukraine invention patent and provides the ability to control the phase discriminator (PD) characteristic shape for the transient process duration in PLL system.

Keywords: standard; exact time; self-tuning; optimization; synchronization; control system; IP-technologies.

\section{Inroduction}

The precision measurement of time and frequency is the most common and accurate in a globalized world economy. It comprises the system to ensure measurements unity in the state, high-quality work and technological processes synchronization in science, agro-industrial, environmental, and other economy branches. Objects requiring synchronization information are the following: agro-industrial sector of economy and telecommunications, computer network providers, metrology service, digital television, bank information infrastructures, power systems, aviation and rail transport, oil and gas pipelines, and so on [1-4].

The existing technical equipment in Ukraine doesn't have a unified system for transmitting exact time signals and, accordingly, cannot meet all consumer requirements for time and frequency information. Therefore, the emphasis is placed on the actual research of new solutions for the time scale transfer using IP technologies and autotuning synchronization devices. Those devices are used in systems for exact time and frequency signal transmission.

\section{Research objective}

The exact time signal source is the state standards of frequency and time or services of the exact time that support the coordinated national time scale. In Ukraine, this source is the primary and secondary time and frequency standard of the State Enterprise "Ukrmetrteststandard" (hydrogen high-power generators operating in continuous mode, which form a time and frequency measure), and the created timescale shaper (precision clock of current time). The second device is a counter with the time signal encoding system for further transmission using timeservers and communication lines, in which clock signals are 
distributed over synchronization objects [5]. Spreading medium is represented by electromagnetic guiding systems (copper and optical cables, radio channels, satellite channels, etc.).

It is established that there is a possibility to distribute synchronous information with sufficiently high accuracy (from one to hundreds nanoseconds) through synchronous or plesiochronous digital hierarchy telecommunication networks [3]. It is necessary to take into account the fact that telecommunication operators are actively developing asynchronous packet switched networks (IP networks), according to the growing demand for Internet services and data transmission. It is obvious that there is a decision to transfer synchronous information to existing IP networks based on the Precision Time Protocol (PTP), which allows distributing the time scale up to hundreds nanoseconds in real networks $[6,7]$.

It should be noted that the PTP is a protocol for the bilateral message exchange between the "master" and "slave", which contain a timestamp. As a result of the exchange, the receiver calculates the correction to the current time scale and adjusts it to the value given by the transmitter. The time scale distribution accuracy depends on the network state. In the overloaded networks, the time transmission accuracy will be much worse, which is explained by the equipment characteristics $[8,9]$. The requirement to improve the transmission quality of exact time and frequency signals determines the topic relevance associated with the autotuning optimization for the synchronization devices.

\section{Synchronization device optimization \\ Synchronization device optimization
according to the performance-optimal phase-locked system}

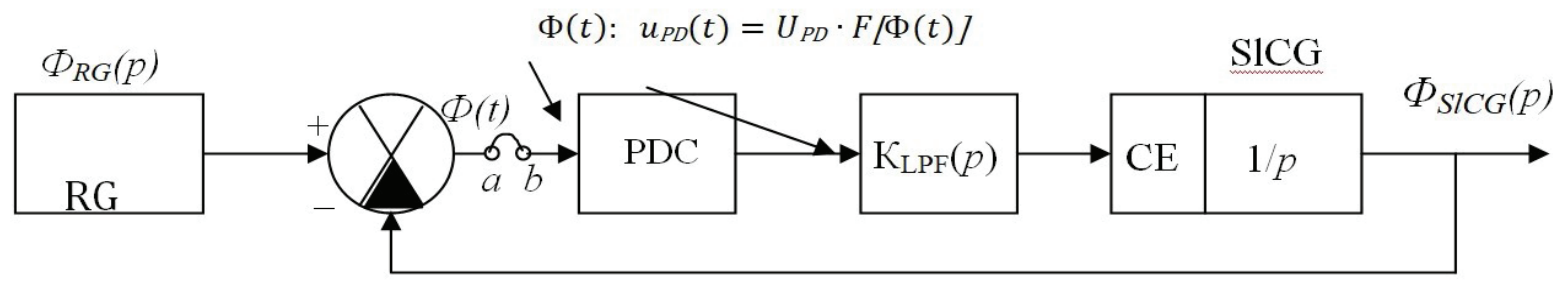

Fig. 1. Typical structural scheme of PLL SD
Let us begin with the exact time scale reproduction and the phase and time synchronization in digital signals, through which the information is transmitted from the sender (transmitter) to the receiver. This process can be realized by the construction of a closed system of automatic regulation (SAR) - a synchronization device (SD) using a phase discriminator (PD). Accordingly, we will call the SAR with the PD phase synchronization system (PSS). PLL systems are PSS basis [1-4]. In the SD, the input and output signals are synchronized by controlling the feedback ring based on the value of the phase difference (system error) between them. The automatic control task in the PLL system consists in a received signal restoration from the standard, its filtration, and the exact adjustment the significant moments of the SD source signal.

Fig. 1 shows a linearized PLL system model, which is presented taking into account the Laplace space. The PLL system characteristics depend on the low pass filter (LPF). In the first order PLL system, the LPF has a wide bandwidth, that is, its transfer function is $K_{\mathrm{LPF}}(\mathrm{p}) \equiv 1$. In the PLL system model in this figure, a slave clock generator is a voltage-controlled oscillator. In this form, the slave clock generator is represented as an integrator.

In Fig. 1, the following elements are specified: ЕГ - reference generator; ФД - phase discriminator; $\Pi$ - the phase difference converter (system errors) into the control signal; $\mathrm{K}_{\Phi \mathrm{H} \Psi}(p)$ LPF transfer function; KE - control element; ВдТГ - slave clock generator; $\varphi(t)=\varphi_{\mathrm{ЕГ}}(t)-\varphi_{\text {ВдТГ }}(t)$ - the PLL system error; $\varphi_{\mathrm{EГ}}(t)$ and $\varphi_{\mathrm{BдT \Gamma}}(t)$ respectively, the reference generator phase and slave clock generator; $p$ - the Laplace operator. 
Let us formulate the problem of performanceoptimal PLL SD control over deviations. We will do this under conditions that the control action on the system object is a signal at the PD output $\mathrm{u}_{\mathrm{PD}}(\mathrm{t})=\mathrm{U}_{\mathrm{PD}} \mathrm{F}[\mathrm{P}(\mathrm{t})]$, which is formed by the converter $\mathrm{P}$ as a result of processing the phase difference $\mathrm{P}(t)$ signal (system errors) $\varphi(t)=\varphi_{\mathrm{E} \Gamma}(t)$ $\varphi_{\mathrm{BдTГ}}(t)$ ( $a b$ points in Fig. 1).

In this case, the PLL PD system control object behavior will be written by the following system of equations:

$$
\left\{\begin{array}{l}
\frac{d \varphi(t)}{d t} \cdot \frac{1}{K_{L P F}}=\Omega_{S} \pm S_{C E} \cdot u_{P D}(t) ; \\
u_{P D}(t)=U_{P D} \cdot F[\Phi(t, n)] ; \\
F[\Phi(t)]=F\left[\varphi(t)+n T_{\varphi}\right] \forall n=\overline{-\infty,+\infty} ; \\
-1 \leq F[\Phi(t)] \leq 1,
\end{array}\right.
$$

where $\Omega_{\mu}$ - initial system arrangement (external excitement); $S_{y}$ - the control element (CE) stepless characteristic; $F[\varphi(t)]$ is the normalized PD characteristic; $U_{Ф Д}$ and $T_{\varphi}$ - respectively, the control action amplitude and the PD discriminatory characteristics period; $t$ is an independent variable (time).

The first type model specificity is to take into account the periodicity of the control action in the system phase coordinate function, which is formed by a phase discriminator. A novelty of the results is a study of performance-optimal PLL SD systems, which take into account control actions with periodicity by phase coordinates.

Suppose that in the phase space $\mathrm{F}$ of the system control object states (1), the two varieties $\mathrm{F}_{0}$ and $\mathrm{F}_{\mathrm{K}}(k \leq n)$ are given. It is necessary that the depicting point, which is obtained in the general case with a previously undeclared position (in a partial case, this position can be given and determined by known initial system conditions), has reached another arbitrary position (it can also be given: the system's coordinates origin, in the stable equilibrium point vicinity), with allowable control excitations with given accuracy, so that the integral optimality criterion took the smallest value as a functional.

$$
T=\int_{t_{0}}^{t_{k}} 1 \cdot d t \Rightarrow \min
$$

The type model feature (1) is a presence of two interconnected control parameters $u_{P D}(t)$ and $T_{\varphi}$ for the next complete group events:

$$
\begin{aligned}
& \text { 1) } u_{P D}(t)=\operatorname{var}, T_{\varphi}=\text { var; } \\
& \text { 2) } u_{P D}(t)=\operatorname{var}, T_{\varphi}=\text { const } ; \text { e.g. } T_{\varphi}=2 \pi \\
& \text { 3) } u_{P D}(t)=\text { const }, T_{\varphi}=\text { var; } \\
& \text { 4) } u_{P D}(t)=\text { const }, T_{\varphi}=\text { const } .
\end{aligned}
$$

The last two variants have a contradiction in a very physical nature of processes that occur in PLL systems, and therefore are not investigated in this research.

Moreover, we should note that the functional (2) as the optimality criterion is a definite integral with moving integration boundaries, which makes it possible to find its optimal values $T_{\text {opt }}$ on two variables $\mathrm{u}_{\mathrm{PD}}(\mathrm{t})$ and $\mathrm{T} \varphi$.

Let us define the Hamiltonian $H$ function from the system (1) as the maximum control action value for all $t$ in a given interval $t_{0} \leq t \leq t_{k}$ in a given region for admissible control parameters $u(t)$ and $T_{\varphi}$, taking into account the infinite LPF bandwidth $K_{\Phi H Y}(t)=1$ :

$$
\mathrm{H}=\mathrm{H}\left(u, T_{\varphi}, \psi_{k}, \varphi, \Omega_{H}\right)
$$

with observance conditions of constancy in time

$$
\mathrm{H}\left(u, \mathrm{~T}_{\varphi}, \Psi, \varphi, f\right) \geq 0,
$$

where $\psi$ - nonzero continuous auxiliary function [5].

The Hamiltonian function is determined as a product the auxiliary variable $\Psi$ on the right side in the first equation of the system (1), that is:

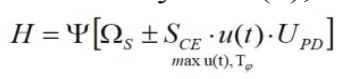

To find the maximum Hamiltonian (6) for the control action $u(t)$, it is necessary to determine the auxiliary function $\Psi$ :

$$
\frac{d \varphi(t)}{d t}=-\frac{\partial H}{\partial \varphi(t)}=0,
$$

which will have the following solution:

$$
\Psi(t)=\Psi_{0}=\text { const },
$$

where $\Psi_{0}-$ unknown initial condition of the auxiliary variable $\Psi(t)$.

The control that maximizes the Hamiltonian, provided the maximum value $u(t)$ in the inequality in system (1) and equality (8), we obtain the 
optimal algorithm in the following form with $\pm S_{y} \cdot U_{\text {Фд }}=$ const $:$

$$
u(t)=U \cdot \operatorname{sign}[\Psi(t)]=U \cdot \operatorname{sign} \Psi_{0}= \pm U
$$

We will form the requirements to the form with the normalized PD characteristic, according to the analytical form obtained in $T_{\varphi}=v a r$ the optimal law of PLL DS system control with an infinite LPF bandwidth (9):

1. The signal at the PD output for the phase (frequency) error duration in the PLL SD system must have a maximum $u=+U$, or a minimum $\mathrm{u}=-U$ value, depending on the initial state. According to the theorem on $n$-intervals with the performance-optimal motion, we have one motion interval. Conclusion: the normalized characteristic PD $F[\varphi(t)]$ should be in the interval of optimal motion (dynamics), nonperiodic time function, and take a constant value equal to the maximum amplitude $u=+U$ or the minimum amplitude $\mathrm{u}=-U$, depending on the initial stat. (Fig. 2b). In the static, the characteristic $F[\varphi(t)]$ is periodic, as shown in Fig. 2a. The performance-optimal modes duration of transient processes is determined by the magnitude of the phase (frequency) error in the PLL SD system.

2. Formation the given $\mathrm{PD}$ characteristics, optimal in terms PLL SD systems' performance, must be carried out by a control channel (third input) that needs to be supplemented by PD to form optimal control action. The channel input receives the optimal switching signal $\sigma(t)$, which provides the PD characteristic form control for the transient process duration, depending on the magnitude and phase (frequency) error sign of the performanceoptimal PLL system. The PD control channel provides for $T_{o p t}$ the fastest and most accurate hit of the system's displaying point in a stable equilibrium position for cases like $T_{\varphi}=v a r$ and $T_{\varphi}=$ const.

\section{Practical implementation of the performance-optimal operation law}

The practical implementation of the performance-optimal law can be ensured by using the proposed adaptive digital phase discriminator (ADPD), which is protected by the patent in Ukraine for the invention [10].
The inventive task is, firstly, to provide an adaptive controlled generation about a code combination on the phase shift angle magnitude of two mutually independent periodic pulse sequences. Secondly, another task is to increase the reliability of representing the measurements results in a digital form by changing the design. Fig. 3 shows the proposed device scheme. ADPD contains the input, where the first pulse signal (Bx.1) and input, where the second pulse sequence signal (Bx.2) is applied. Also, it contains the presetting $\mathrm{K}$-inputs pulse counter (numbered 1 ... k) that is $\mathrm{K}$ digital inputs of the device pre-installation code (optimal switching $\sigma(\mathrm{t})$ ). Moreover, the ADPD contains $n$-outputs - the digital outputs in the device, where a code combination is formed corresponding to the time mismatch between the first and second input pulse sequences.

The device works in the following way. The mold formed by the first input pulse sequence enters the input Bx.1, and the second input pulse sequence enters the input Bx.2 in the ADPD (Fig. 3 ). The code combination, which will be formed at outputs $1 \ldots \mathrm{n}$, corresponds to the phase shift value between the input pulse sequences and is a representation of the measured phase difference in the digital form.

The code is applied to the additional K-inputs (numbered $11 \ldots \mathrm{k}$ ), which are $\mathrm{K}$ digital preinstallation inputs of the ADPD code, corresponding to the required value of the adaptive digital phase discriminator initial state. The obtained possibility to change the initial device state allows providing an adaptive controllable formation a code combination about the phase shift angle magnitude of two mutually independent periodic pulse sequences. 


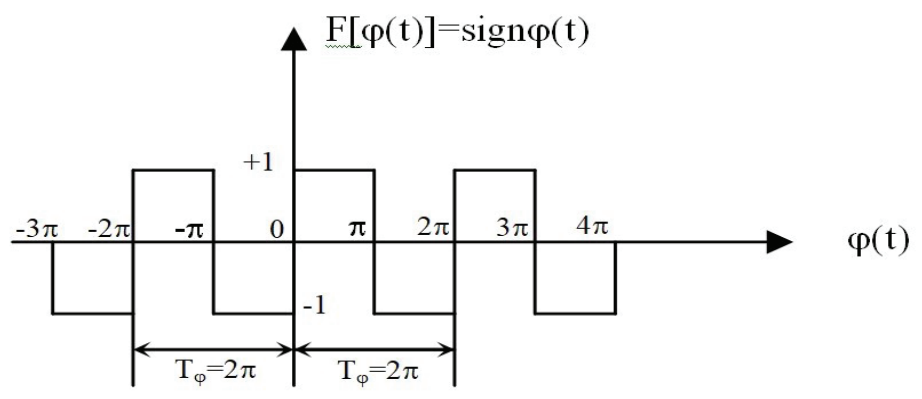

a)

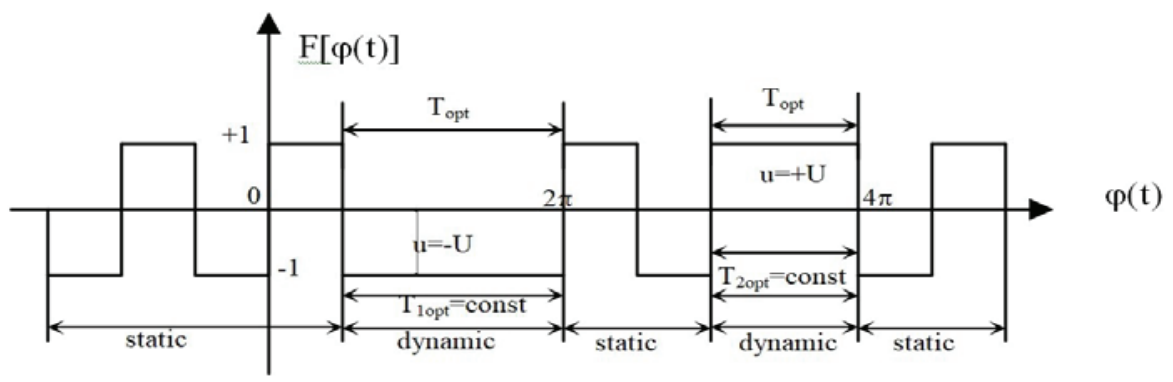

b)

Fig. 2. Shapes of standardized characteristic of phase discriminators:

a) ordinary rectangular normalized characteristic at $T_{\varphi}=v a r, u= \pm U$; б) optimal control for the periodic characteristic of the PD $F(\varphi)=$ const, at $u=-U, T_{\varphi}=T_{1 \text { opt }}$ (dynamics with the interval $T_{1 \text { opt }}$ ) and $F(\varphi)=c o n s t$, at $u=+U ; T_{\varphi}=T_{2 \text { opt }}$ (dynamics with the interval $\left.T_{2 \text { opt }}\right)$.

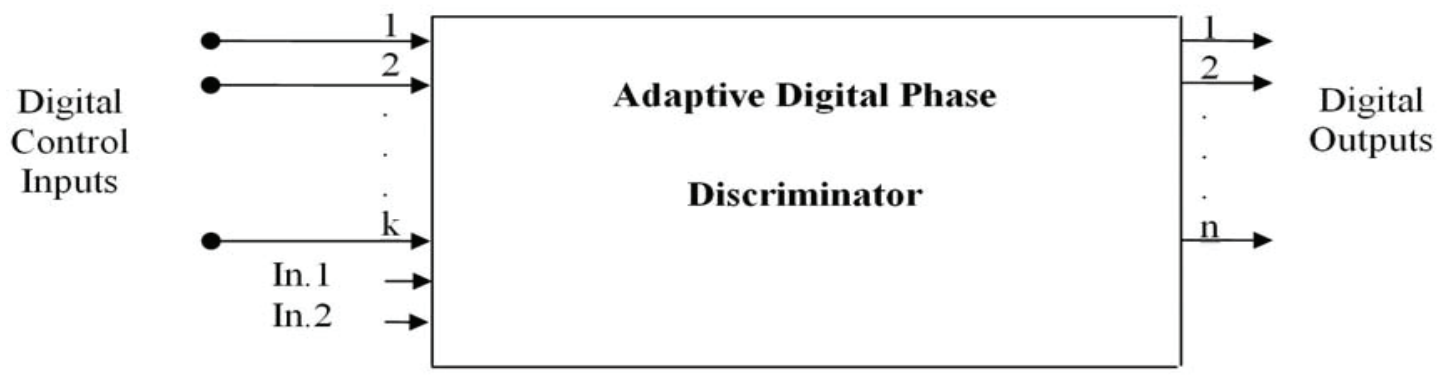

Fig. 3. ADPD scheme

The technical solution of the invention provides an adaptive controlled formulation the code combination and enhances the reliability for representation the measurement results in a digital form. The ADPD control allows it to be used in modern intelligent, adaptive, optimal automation systems, devices for measuring the phase difference/time in periodic signals $[11,12]$.
The ADPD usage in the PLL SD system provides the PD characteristic form control for the transient process duration, depending on the magnitude and sign of the phase (frequency) error. The PD control channel provides the fastest and most accurate hit the reflecting point in the PLL $\mathrm{SD}$ system in a stable equilibrium position and, as a result, realizes the performance-optimal control in the system. 


\section{Conclusions}

1. The existing technical equipment in Ukraine doesn't have a unified system for transmitting exact time signals and, accordingly, cannot meet the requirements for all consumers with frequency-time information.

2. The decision to transfer synchronous information to existing IP networks based on the PTP precision time protocol is obvious. This protocol allows the distribution with time scale up to hundreds nanoseconds in real networks.

3. Improving the signals transmission quality of exact time and frequency determines the need to optimise the PLL synchronization device system performance.

4. The proposed ADPD in the PLL system with PS provides a minimum duration of the transient process.

5. The ADPD control allows its application in modern intelligent, adaptive, optimal automation systems, devices for measuring the phase/time difference in periodic signals in telecommunications, metrology, power engineering. It can also be used in automation, computer, and information technologies to compare the phases of two mutually independent oscillations in order to measure the phase shift angle between them and presenting the result in a digital form.

\section{References}

1. Breny S. Synchronization of digital Telecommunications networks: Translated from English. - Moscow: Mir, 2003. - 456p.

2. Automated transmission system of synchronous signals using IP networks: monograph / V.V. Koval, D.O.Kalian, O.V. Samkov. - Kyiv: National University of Life and Environmental Sciences of Ukraine, 2016. - 182 p.

3. Koval V.V. Devices of synchronization in infocommunication networks with periodic selfrepair: monograph / V.V. Koval, D.O.Kalian. Kyiv: National University of Life and Environmental Sciences of Ukraine, 2016. - 412 p.

4. Increasing the dynamic accuracy and performance of traditional phase auto-tuning and PLL systems. Monograph / Krivutsa V.G., G.F.
Zaitsev, V.L. Bulgach, A.V. Samkov [et. al.]. Kyiv: NASU Institute of Electrodynamics, 2013. $227 \mathrm{p}$.

5. Velychko O.N., Golovnya M.V. Secondary standard of time units and frequency as a source of synchronization signals and time // Telecommunication, 2013, № 2. - P. 22-25.

6. Ingram D.M., et al. Perfomance Analysis of PTP Components for IEC 61850 Process Bus Applications, IEEE Transactions on Instrumentation and Measurement, Vol.62, No. 4, April 2013, pp.710-719.

7. Milentiy Golovnya, Igor Shkliarevskyi, Oleh Velychko, Valeriy Koval, Oleksii Nikitenko. "IEEE 1588 Based National Time-scale Distribution Project in Ukraine", International IEEE Symposium on Precision Clock Synchronization for Measurement Control and Communication (ISPCS), 2016, September 04-09, Sweden, 2016.2 pp.78-82. http://ieeexplore.ieee.org/document/7579513/autho rs?ctx=authors

8. Konovalov, G., Kostik, B., Koval, V., Shkliarevskyi, I. "Timing information's $24 \times 7$ monitoring as an important factor of network synchronization quality support", 2013 International IEEE Symposium on Precision Clock Synchronization for Measurement Control and Communication (ISPCS-2013), Digital Object Identifier: $\quad$ 10.1109/ISPCS.2013.6644769. September 22-27, Lemgo, Germany. 2013. - P.8994.

http://ieeexplore.ieee.org/search/searchresult.jsp?n ewsearch $=$ true \&queryText $=$ Precision $\% 20$ Clock $\% 2$ 0Synchronization $\% 20$ For $\% 20$ Measurement $\% 20 \mathrm{Co}$ ntrol\%20And\%20Communication\%20.LB.ISPCS. RB.,\%202013\%20International\%20IEEE\%20Sym posium $\% 20 \mathrm{On}$

9. Koval V.V., Kalian D.O., Tepliuk V.M., Shkliarevskii I.I., Khudyntsev M.M. Multichannel Clock Signal Monitoring System for Infocommunication Networks // Proc. International Conf. "Modern problems of Radio Engineering, Telecommunications and Computer Science" (TCSET'2016). - Lviv-Slavske, Ukraine, 23-26 February, 2016. Lviv: Lviv State Polytechnic University. $\quad-\quad 2016 . \quad$ pp.618-620. http://ieeexplore.ieee.org/xpl/login.jsp?tp=\&arnum ber $=7452132 \&$ url $=$ http $\% 3 \mathrm{~A} \% 2 \mathrm{~F} \% 2$ Fieeexplore.ie 
ee.org\%2Fxpls\%2Fabs_all.jsp $\% 3$ Farnumber $\% 3 \mathrm{D} 7$ 452132

10. Patent for invention №113473 Ukraine, IPC (2016.01) H 03 D 13/00, H 03 D $3 / 04$ (2006.1). Adaptive Digital Phase Discriminator. Patent №113473 Ukraine, IPC (2016.01) H 03 D 13/00, H 03 D 3/04 (2006.1) / V.V. Koval, D.O.Kalian, V.V. Koval (Ukraine) - № a 2015 11981, Applied on 03.12.2015, Published application information 10.05.2016, Journal № 9 . Published bulletin №2, 25.01.2017.

11. National Information and Communication Infrastructure Management Systems: Monograph /
Krivutsa V.G., Berkman L.N., Koval V.V., Lysenko V.P., Kilchytsky Ye.V. [et. al.]. Kyiv: "CPU" COMPRINT", 2013. - 310p.

12. Development of the concept of scientific and applied principles for the creation a single information system for the distribution of the national time scale using IP technologies: Report on state-commissioned research work by public order / National University of Life and Environmental Sciences of Ukraine; State registration number: 0115U003376. - Kyiv, 2016. $-172 \mathrm{p}$.

Received in final form on February 25, 2018 
Кальян Д.О.

Оптимальна за швидкодією система фазової автопідстройки частоти пристрою синхронізації та формування сигналів точного часу

Проблематика. В умовах сьогодення задачі формування сигналів точного часу для задоволення вимог усіх споживачів частотно-часової інформації направлені на дослідження підвищення якості систем передавання шкали часу з використанням IP-технологій та оптимізації автопідстройки пристроїв синхронізації, як одних із найбільш поширених елементів системи.

Мета досліджень. Оптимізація за швидкодією системи фазової автопідстройки частоти (ФАПЧ) пристрою синхронізації та формування сигналів точного часу.

Методика реалізації. Побудова лінеаризованої моделі замкнутої системи автоматичного регулювання пристрою синхронізації, отримання в аналітичному виді оптимального за швидкодією закону керування та його реалізація в системі ФАПЧ пристрою синхронізації за допомогою адаптивного цифрового фазового дискримінатора.

Результати досліджень. Практична реалізація оптимального за швидкодією закону керування в системі ФАПЧ пристрою синхронізації з використанням адаптивного цифрового фазового дискримінатора.

Висновки. Передачі синхроінформації діючими IP-мережами на основі протоколу РТР, дозволяє розповсюджувати шкалу часу з точністю до сотень наносекунд у реальних мережах. Підвищення якості формування сигналів точного часу обумовлює необхідність проведення оптимізації за швидкодією системи ФАПЧ пристроїв синхронізації. Використання адаптивного цифрового фазового дискримінатора, який захищено патентом України на винахід, в системі ФАПЧ забезпечує можливість керування формою характеристики фазового дискримінатора (ФД) на тривалість перехідного процесу.

Ключові слова: еталон; точний час; автопідстройка; оптимізація; синхронізація; керування; IPтехнології.

Кальян Д.А.

Оптимальная по быстродействию система фазовой автоподстройки частоты устройства синхронизации и формирования сигналов точного времени

Проблематика. В настоящих условиях задачи формирования сигналов точного времени для удовлетворения потребностей всех потребителей частотно-временной информации направлены на исследование повышения качества систем передачи шкалы времени с использованием IP-технологий и оптимизации автоподстройки устройств синхронизации, как одних из наиболее распространенных элементов системы

Цель исследований. Оптимизация по быстродействию системы фазовой автоподстройки частоты (ФАПЧ) устройства синхронизации и формирования сигналов точного времени.

Методика реализации. Построение линеаризованной модели замкнутой системы автоматического регулирования устройства синхронизации, получение в аналитическом виде оптимального по быстродействию закона управления и его реализация в системе ФАПЧ устройства синхронизации с помощью адаптивного цифрового фазового дискриминатора.

Результаты исследований. Практическая реализация оптимального по быстродействию закона управления в системе ФАПЧ устройства синхронизации с использованием адаптивного цифрового фазового дискриминатора.

Выводы. Передача синхроинформации по действующим IР-сетям на основе протокола РТР, позволяет распространять шкалу времени с точностью до сотен наносекунд в реальных сетях. Повышение качества формирования сигналов точного времени обуславливает необходимость проведения оптимизации по быстродействию системы ФАПЧ устройств синхронизации. Использование адаптивного цифрового фазового дискриминатора, который защищен патентом Украины на изобретение, в системе ФАПЧ обеспечивает возможность управления формой характеристики фазового дискриминатора (ФД) на длительность переходного процесса.

Ключевые слова: эталон; точное время; автоподстройка; оптимизация; синхронизация; управление; IPтехнологии. 